\title{
Достижения по селекции кормовых культур в Сибирском НИИ Кормов СФНЦА РАН за 50 лет
}

Камеваров Н.И., д.с.-х.н., академик РАН, директор; Полюдина Р.И., д.с.-х.н., рук. селекционного центра по кормовым культурам; Потапов Д.А., к.с.-х.н., в.н.с.; Гришин В.М., к.с.-х.н., с.н.с.

Сибирский федеральный научный центр агробиотехнологий РАН, Новосибирск, Россия.

e-mail: sibkorma@ngs.ru

В селекиионном иентре СибНИИ кормов СФНЦА РАН создано более 60 сортов по 24 кормовым культурам, в Государственный реестр включен 51 сорт. Впервые в Сибири созданы безэруковые, низкоглюкозинолатные, высокоурожайные сорта ярового рапса СибНИИК 198, СибНИИК 21, Дубравинский скороспельий, Надежный 92 и Сибирский; уникальные скороспелые и высокоурожсайные сорта сои СибНИИК 315, СибНИИК 9, Горинская и кормовых бобов Сибирские; зимостойкие одно- и двуукосные на диплоидной и тетраплоидной основе сорта клевера лугового СибНИИК 10, Родник Сибири, Атлант, Огонек, Памяти Лисицьна, Метеор, Прима; редька масличная Сибирячка.

Ключевые слова: селекиия, яровой рапс, соя, суданская трава, клевер луговой, бобы кормовые, редька масличная.

\section{Progress in forage crops breeding in Siberian Research Institute of Forage Crops SFSCA of The RAS for fifty years}

Kashevarov N.I., Polyudina R.I., Potapov D.A., Grishin V.M., Siberian Federal Scientific Centre of Agro-BioTechnologies of the Russian Academy of Sciences; Novosibirsk, Russian Federation, sibkorma@ngs.ru

As many as sixty cultivars of twenty four fodder crops were developed in a breeding center of Siberian research Institute of forage crops of SFSCA of the RAS. Fifty-one cultivars are included in the State register of breeding achievements. High-yielding canola varieties such as SibNIIK 198, SibNIIK 21, Dubravinsky skorospeliy, Nadezhny 92 and Sibirsky, and unique early-maturing and high-yielding soybean varieties SibNIIK 315, SibNIIK 9, Gorinskaya, fodder beans Sibirskye, and winter-hardy diploid and tetraploid meadow clover varieties SibNIIK 10, Rodnik Sibiri, Atlant, Ogonyok, Pamyati Lisitsyna, Meteor, Prima, and oilseed radish Sibiryachka are created for the first time in Siberia.

Key words: breeding, Brassica napus, Glycine max, Sorghum sudanense, Trifolium pratense, Faba vulgaris, Raphanus sativus var. Oleiformis. 
В 1970 г. решением ВАСХНИЛ был учрежден Сибирский научно-исследовательский институт кормов с отделом селекции и семеноводства, на базе которого в 1977 году был создан Сибирский селекционный центр по кормовым культурам. В его состав в настоящее время входят региональные отделы: Северо-Кулундинский (г. Баган Новосибирской области) и Восточно-Сибирский (с. Михайловка Ужурского района Красноярского края), организованные на базе сельскохозяйственных опытных станций. Это позволяет вести селекцию на адаптивность к условиям лесостепной и степной зон Западной и Восточной Сибири. За годы функционирования селекцентра создано более 60 сортов по 24 кормовым культурам, в Государственный реестр включен 51 сорт.

Первый в СССР сорт ярового panca Восточно-Сибирский был создан на Ужурской СХОС (Восточно-Сибирский отдел СибНИИ кормов) в 1981 г. Из 145 сортов включенных Государственный реестр в 2019 г., 52 - включены по Западно- и Восточно-Сибирскому регионам, среди которых 8 - сибирской селекции. Сорта СибНИИ кормов: СибНИИК 21, СибНИИК 198, Дубравинский скороспелый, Надежный 92, Сибирский [1]. Начатые в СибНИИ кормов в 1987 г. исследования по получению ярового рапса 000-типа с использованием методов отдаленной гибридизации и инбридинга [2] привели к созданию нового высокоурожайного и высокомасличного сорта СибНИИК 32 , который в 2018 г. передан на ГСИ.

В Сибири до 1993 года возделывались местные сорта клевера лугового, районированные еще в 1940-х годах прошлого столетия и селекционные сорта, созданные методом массового отбора. С созданием селекцентра по кормовым культурам взяты на вооружение современные селекционно-генетические методы: гетерозисная селекция, гибридизация, мутагенез и полиплоидия. В СибНИИ кормов создана серия сортов нового поколения пластичных, высокоадаптивных, зимостойкие, высокоурожайные одноукосные и двуукосные на диплоидной и тетраплоидной основе [3].

Применительно к клеверу луговому во ВНИИ кормов разработана селекционная схема эффективного использования метода химического мутагенеза, обеспечивающая создание новых признаков и их закрепления, сокращение сроков селекции на первых этапах в 1,5-2 раза в условиях искусственного климата. Впервые решена сложная проблема селекции клевера лугового на скороспелость, где преодолена генетическая отрицательная корреляционная связь между признаками зимостойкости и скороспелости генотипов клевера лугового [4].

В результате сочетания методов мутагенеза, полиплоидии, гибридизации и отбора в жестких климатических условиях Западной Сибири впервые создан раннеспелый (двуукосный) зимостойкий на тетраплоидной основе сорт Метеор. Урожайность зеленой массы в первом укосе у сорта варьировала от 177 до 520 ц/га, во втором укосе от 105 до 486 ц/га. Максимальная 
урожайность за два укоса у сорта установлена 700 ц/га - $112 \%$ к стандарту СибНИИК 10 (2001 год) [5]. Облиственность в первом укосе у сорта Метеор составляет 36-48 \%, во втором укосе 32-53 \%; у стандарта - 36-44 и 40-49\%.

Сорт Прима раннеспелого типа на диплоидной основе создан совместно с ВНИИ кормов методом гибридизации и отборов. Средняя урожайность зеленой массы за два укоса 388 , сухого вещества 86, семян 3,17 ц/га [6]. Урожайность семян у нового сорта Прима варьировала по годам от 2,76 до 3,92 ц/га, при этом в сравнении с диплоидным стандартом СибНИИК 10 в 2007 и в 2009 была на уровне, а в 2011 году превышение составило 18 \%, а в сравнении с тетраплоидным стандартом Метеор диплоидный сорт Прима превышал по этому показателю на 36-93 \% в среднем на 52 \% (табл. 1). Сорт включен в Госреестр в 2019 г.

Таблица 1 - Урожайность семян клевера лугового растений первого года пользования сорта Прима (конкурсное сортоиспытание), ц/га

\begin{tabular}{|c|c|c|c|c|c|c|}
\hline \multirow{3}{*}{$\begin{array}{c}\text { Год } \\
\text { посева }\end{array}$} & \multicolumn{5}{|c|}{ Урожайность } & \multirow{3}{*}{$\mathrm{HCP}_{05}$} \\
\hline & \multirow{2}{*}{$\begin{array}{l}\text { Метеор, } \\
\text { ст.1 }\end{array}$} & \multirow{2}{*}{$\begin{array}{c}\text { СибНИИК } 10, \\
\text { ст. } 2\end{array}$} & \multicolumn{3}{|c|}{ Прима } & \\
\hline & & & $ц / г а$ & $\begin{array}{c} \pm \mathrm{\kappa} \\
\text { ст. } 1 / \mathrm{c} \text {. } 2\end{array}$ & $\begin{array}{c}\% \text { к } \\
\text { ст.1/ст.2 }\end{array}$ & \\
\hline 2006 & 1,96 & 2,88 & 2,83 & $0,87 /-0,05$ & $144 / 98$ & 0,44 \\
\hline 2008 & 2,88 & 4,33 & 3,92 & $1,04 /-0,41$ & $136 / 91$ & 0,35 \\
\hline 2010 & 1,43 & 2,34 & 2,76 & $1,33 / 0,42$ & $193 / 118$ & 1,11 \\
\hline Среднее & 2,09 & 3,18 & 3,17 & $1,08 / 0,01$ & $152 / 99$ & - \\
\hline
\end{tabular}

Работа по селекции сои в Сибири была начата в 1950-х годах. Первый сибирский уникальный сорт СибНИИК 315 создан путем отбора, включен в Госреестр РФ с 1991 г. и допущен к использованию в 5 регионах России и Казахстане. В лесостепи Западной Сибири он вызревает за 90-110 дней, дает до 30 ц/га семян с содержанием белка 35-40 \%, масла 17-20 \%. Высокая экологическая пластичность сорта обеспечивает его широкое распространение: в настоящее время он возделывается от Москвы до Иркутска, превосходя по ареалу все другие российские сорта, и пользуется большим спросом. В настоящее время созданы высокоурожайные сорта сои СибНИИК 9 [7] и Горинская. Самая высокая урожайность зерна у этих сортов была установлена в 2017 г., она составила соответственно 33,6 и 29,2 ц/га [8].

Впервые в условиях Сибири в СибНИИ кормов совместно с Алтайским НИИСХ создан сорт кормовых бобов Сибирские. Сорт создан методом индивидуального (трехкратного) отбора из гетерогенной популяции К-2083 (Германия). Он характеризуется урожайностью зеленой массы 300 , сухого вещества -70 , зерна -35 ц/га. Вегетационный период от всходов до уборки на корм - 55 дней, на зерно 91-99 дней [9].

Одними из самых распространенных сортов суданской травы в Си- 
бири являются: Новосибирская 84, Лира, Туран 2, Кулундинская. В Государственном реестре селекционных достижений зарегистрировано 43 сорта суданской травы, их которых 21 районированы по Сибири. Сорта суданской травы, возделываемые в Сибири должны обладать не только высокими хозяйственно ценными признаками продуктивности, но и повышенной устойчивостью к неблагоприятным факторам внешней среды (табл. 2).

Таблииа 2 - Модель сорта суданской травы для возделывания в условиях Сибири

\begin{tabular}{|l|c|}
\hline \multicolumn{1}{|c|}{ Признаки } & Параметры \\
\hline Вегетационный период & $100-110$ дней \\
\hline Урожайность зеленой массы & $250-350$ ц/га \\
\hline Урожайность сухой массы & $40-50$ цга \\
\hline Урожайность семян & $15-20$ ц/га \\
\hline Интенсивность начального роста & средняя или высокая \\
\hline Выравненность по высоте растений и спелости семян & выровненные \\
\hline \multirow{2}{*}{ Устойчивость к заболеваниям } & $\begin{array}{c}\text { средне- и высоко-устой- } \\
\text { чивые }\end{array}$ \\
\hline
\end{tabular}

В СФНЦА РАН селекция суданской травы ведется с 1983 г. За это время было сформировано более десятка сложногибридных и синтетических популяций суданской травы [10]. Создано 5 сортов: Новосибирская 84, Лира, Достык 15 (совместно с ТОО Павлодарским НИИСХ), Карагандинская (совместно с ТОО Карагандинским НИИРС), Ника (совместно с ТОО «Научнопроизводственный центр зернового хозяйства им. Бараева» Республики Казахстан).

В 2018 г. создан новый сорт редьки масличной Сибирячка, урожайность семян составила 14,3 ц/га, на $12 \%$ выше стандарта, урожайность зеленой массы - 371,4 ц/га, что превышало стандарт на 18 \%. Продолжительность вегетационного периода составила 95 дней. Сорт может успешно возделываться во всех земледельческих регионах РФ [11].

Таким образом, за пятьдесят лет исследований достигнуто расширение сибирского генофонда по яровому рапсу, сое, клеверу луговому, суданской траве, кормовым бобам и другим кормовым культурам.

\section{Список литературь}

1. Осипова Г.М., Потапов Д.А. Рапс (Особенности биологии, селекция в условиях Сибири и экологические аспекты использования) / Россельхозакадемия. Сиб. отд-ние. - Новосибирск, 2009. - 132 с.

2. Потапов Д.А. Увеличение биоразнообразия в пределах вида Brassica napus L. при селекции на желтую окраску оболочки семян / Генофонд и селекция растений: мат. VI Междунар. науч.-практ. конф. (4-6 апреля 2018 г., Новосибирск, Россия). Новосибирск, ИЦиГ СО РАН, 2018. - С. 322-327. 
3. Полюдина Р.И. Экологическая селекция клевера лугового для создания сортов с повышенной адаптивностью к отрицательному воздействию температурных факторов среды в условиях Западно-Сибирского региона / Экологическая селекция и семеноводство клевера лугового. - М., 2012. - С. 77-103.

4. Новоселов М.Ю. Селекция клевера лугового. - М., 1999. - С. 183.

5. Полюдина Р.И. Селекционный потенциал клевера лугового в Сибири // Сиб. вестн. с.-х. науки. - 2016, №5. - С. 106-112.

6. Полюдина Р.И. Клевер в Сибири / СФНЦА РАН. - Новосибирск, 2017. $348 \mathrm{c}$.

7. Рожанская О.А., Полюдина Р.И. Особенности селекции сои с использованием методов сомаклональной изменчивости и мутагенеза в условиях Западной Сибири // Сиб. вест. с-х. науки, 2012. - №4. - С. 69-76.

8. Кашеваров Н.И., Полюдина Р.И., Данилов В.П., Потапов Д.А. Сорта кормовых культур в Сибири для импортозамещения АПК РФ // Труды Кубанского государственного аграрного университета. - №3 (59), 2016. - С. 167-176.

9. Кашеваров Н.И., Полюдина Р.И., Полищук А.А., Петров А.Ф., Кашеварова Н.Н. Кормовые бобы Сибирские // Кормопроизводство. - 2008. - №4. - С. 20-21.

10. Кашеваров Н.И., Полюдина Р.И., Балыкина Н.В., Штаус А.П. Суданка в кормопроизводстве Сибири / Под ред. Н.И. Кашеварова. - Новосибирск, 2004. - 224 с.

11. Полюдина Р.И., Потапов Д.А., Харчебников В.В. Новый сорт редьки масличной Сибирячка // Сиб. вестн. с.-х. науки, 2018. - Т. 48 (4). - С. 50-54.

DOI 10.18699/GPB2020-33

\section{Использование расширенной панели молекулярных маркеров на гены устойчивости $(S r 21, S r 23, S r 35, S r 36, S r 38)$ к стеблевой ржавчине на сортах мягкой и твердой пшеницы}

Кельбин В.Н. *, м.н.с.; Сколотнева Е.С., к.б.н., с.н.с.; Морозова Е.В., м.н.с.; Салина Е.А., д.б.н., г.н.с. ИЦиГ СО РАН, Новосибирск, Россия.

*e-mail: kelbin@bionet.nsc.ru

Стеблевая ржавчина пшениць - губительное заболевание, которое представляет реальную угрозу для производства пшенищы во всем мире. $C$ каждым годом возрастает вероятность появления и распространения новых вирулентных рас гриба. В этом исследовании мы провели оценку новой расширенной панели молекулярных маркеров (5 доминатных и кодоминатных маркера) на гены устойчивости к стеблевой ржавчине на 11 сортах мягкой и твердой пшениць в комплексе с фитопатологической оценкой к агрессивной западно-сибирской расе Pисcinia graminis f. sp. tritici.

Ключевые слова: молекулярные маркеры, гены устойчивости, анализ вирулентности, стеблевая ржавчина пшеницы. 